УДК 39(571.52)

\title{
Traditional Notion of Time of Nomadic Tuvinians
}

\author{
Shenne Iu. Kuzhuget* \\ Tuvan State University \\ 36 Lenin Str., Kyzyl, Republic Tuva, 667000, Russia
}

Received 15.09.2016, received in revised form 03.07.2017, accepted 12.07.2017

The article deals with the traditional concept of time of the nomadic Tuvinians. Particular attention is paid to the temporal lexical units with a meaning of daily time intervals, which Tuvinians expressed by parts and objects of everyday life of the yurt.

Keywords: linguistic view of the world, time, means of expression, daily cycle, national identity, yurt.

DOI: 10.17516/1997-1370-0105.

Research area: theory and history of culture.

The relevance of the study is determined by the ever growing interest in the place and role of spatial and temporal ideas in the formation of national linguoculture.

The research problem is related to the need to study the temporal aspects of reality in the work of writers as elements of the linguistic view of the world of Tuvinians, which are most fully represented in epic works. The meaning of time in the Tuvan language is expressed by adverbs, nominal forms of indirect cases, adverbial phrases, subordinate clauses, and phraseological phrases.

Representations of the cyclicity of time correspond to natural cycles, namely to daily and annual ones. The calendar of the Tuvinians is related to the nomadic way of life, the rhythm of the seasonal agricultural work, the observation of the alternation of the phases of the moon, natural changes in nature, and others. It was based on the eastern calendar that the peoples of Central Asia used.

An essential feature of the Tuvinian national daily calendar is that the order of the numbering of days in the summer is supplemented by the day time indicators, determined by the sunlit illumination of certain parts of the yurt and some objects in it.

The traditional representation of time among nomadic Tuvinians is a feature of the national worldview and an individual ethnic worldview, since this ethnos is a representative of the nomadic civilization. This category can be called a cultural and ethnic dominant. According to Kornilov, these dominants determine the national characteristics of behavior, attitude and world-view (Kornilov, 2003: 180). Through the perception of the concept of time, the features

(C) Siberian Federal University. All rights reserved

* Corresponding author E-mail address: kuzhuget-sh@mail.ru 
of the national character of the Tuvinians are reflected.

The yurt for the nomad is not only home, it reflects the spatial and temporal representations of the people. Time was not represented in the form of one-dimensional information but in a much more saturated, multidimensional and dynamic way (Darzha, 2007: 46). For nomads, time is an eternal movement in the cosmic circle of the universe. In their small space, the inhabitants of the yurts feel secure and confident.

In this article, temporal lexical units with the value of daily time intervals are considered. Tuvinians determined these time intervals by parts of the yurt and its some household items.

In the Tuvinian phenological calendar, the account of time is organized by nine days, which are grouped into four temperature cycles coinciding mainly with the four seasons of the year. The count is from the winter solstice, after which the day begins to increase. Winter cold nine nine-days are the time of birth and dying of the heat. The spring period (March 14 June 22) is characterized by growing leaves and singing cuckoos. Autumn (September 15 December 22) is the time of yellow leaves and the time of the sun of the elderly; they bask in the sun and say goodbye to it. The very last cycle of these autumn nine-days (November 20 December 23) is called 'the sun of old women' (Traditional..., 1988: 52).

There are certain spatial and temporal indicators that do not specifically indicate time and space, but functionally they are equal members of the space-time classification system. This may include, for example, household utensils, in particular clothes, utensils, tools, plants, pets, etc. (Tsiv'ian, 2006: 13). These are elements of time that are firmly established in the mind of man as pointers of time.

The Tuvinian nomads defined the diurnal circle of time by the reflection of the rays of the sun on certain parts and objects of the yurt in a particular period of the daily time. Such temporal nominators as khana - yurt lattice, kharaacha smoke hole, der - honorary part of the yurt, ezhik - door, ergin - doorstep, as well as interior elements of the yurt such as syrtyk - pillow, orun - bed, aptara - chest, chyyshkyn - things stacked in the pile on the left side of the yurt and others were the peculiar markers of spatial and temporal, socially hierarchical, sacred relations.

As L. Potapov notes, "the shepherds ... drew a small plan of the yurt on the ground and planned the places of some objects on it needed for orientation, then stuck a stick in the middle of such a hastily sketched blueprint and defined time according to the shadow cast by it on the location of one or another object" (Potapov, 1969: 303). For the shepherd domesticated watches were the most convenient measure of time on a pasture or other terrain. A person who knew the language of these signs had no difficulty guiding in a semioticized space.

The common calculation of the Tuvinians' daily time arose because "the yurt of the Tuvinians was strictly oriented with the door in the same direction, while the furniture and accommodation in the yurt were standard" (Potapov, 1969: 302). Thus, the interior of the yurt was a kind of reference point in the spacetime continuum (Traditional..., 1988). In the summertime, when the longitude of the day increases, it is easier and more convenient to determine the daily time by parts and objects of the yurt than in winter. Besides, the definition of the time of day by the yurt was necessary for the distribution of economic activities of Tuvinians for the whole day.

1. Kharaacha - smoke hole is the main yur landmark in the surrounding space for the Tuvinian, which seemed to indicate or set the rhythm of life to all living things on earth. The early morning time after sunrise was determined 
by the contact of the sun's rays on the top of the smoke hole.

(1) Erten ottup kelgesh, karaam korup keerimge, khun chaa-la kharaacha bazhynda shonup kelgen tur. " "When I woke up and opened my eyes, the sun's rays had just touched the smoke hole of the yurt."

2. Der - an honorary place in the eastern part of the yurt - is a sacred place. Here the oldest and most distinguished guests sat. The time of the small half-day is characterized by an honorary place in the yurt, on which the rays of the sun fell.

In the example below, such an orientation in time on a pasture, which is the simplest scheme of a sun clock, is illustrated.

(2) Maakai kurgag khola-kharagan syp algash, cherge togerik shyiyg kylgash, ortuzunga ol-la kharaganyn kadai idip kaan. Shoibek yiashtyn kholegezi chaa-la dor bazhynda khire kezulgen. "Maakai took a dry pea tree, and after drawing a circle on the ground, pushed it in the very middle of this circle. The shadow of an elongated tree was only above the honorary place of the yurt."

The time of a small half-day is characterized by the reflection of the sun's rays on the upper part of the yurt lattice. At this time, "the sun appeared on the tops of the lattice, which made up the skeleton of the yurt. It was a small noon" (Potapov, 1969: 302).

(3) Khun khana bazhynga deep kelgen. ${ }^{3}$ "The sun touched the tops of the yurt lattice."

3. Aptara - chest - is the main attribute of the yurt's interior. It kept the most valuable family things and objects. The time interval a small noon - was determined by the position when "the sun lit up the middle of leather bags and sacks standing in the "front corner" of the yurt" (Potapov, 1969: 302).

(4) Aaldan unerimde, khun dal du'sh, egnun aptara baarynga turgan. ${ }^{4}$ "When I left the aala, it was noon, and the sun's rays fell on the trunk in the yurt."

4. Syrtyk - pillow - is the main keeper of the family hearth, where it "became the focus of life, the guarantee of health and happiness of the family" (Traditional..., 1988: 151). There Tuvinians stored the most intimate things, in particular the umbilical cord of their children, etc. The time of the big noon was determined by the position of the sun such as "it stood on the head of the bed, illuminating the leather cushion syrtyk" (Potapov, 1969: 302).

(5) A am chuu khirel? Syrtyk Bazhy ertken azy moldurgam-bile bistin holegevis boduvustan baza bir yncha khire bedii bergen. "Now what is the time? The rays of the sun passed over the head of the bed or our shadow with the calf also rose so many times."

5. Orun - bed - is the most sacred and taboo subject within the living space. It has never been touched by strangers. The continuation of a large half-day was determined by the appearance of the sun "in the middle of the bed (wooden)" (Potapov, 1969: 302).

(6) Bavuu khun orun bazhy chede bergende, ottup kelgen. 6 "Bavuu woke up when the sun's rays were near the bed in the yurt."

The arrival of the evening time is characterized by the following position of the sun in the sky, "the sun rose behind the legs of the bed. The late, evening noon begins. Women prepare for milking and tie calves, lambs and kids at the milking place" (Potapov, 1969: 302). At this time, the evening activities of the whole aal begin.

(7) Khun orun budunda baryp kudulai bergende, Buian og kholegezinge turup algash, taraa soktan turgan? "When the sun rose behind the feet of the bed, Buian was peeling millet in the shady side of the yurt."

6. The next item of the yurt for defining the daily time is the lexical item of chyyshkyn, which 
means "things stacked on the left side of the yurt". The beginning of the evening time after sunset was determined by its reflection on the left side of the yurt.

(8) (Mangyr cheizen) Koryp keerge, khun chyyshkyn bazhynda kelgen turgan. "When he (Mangyr cheizen) looked in, the sun was on the left side of the yurt."

Thus, in the daytime the main chronograph for determining the daily time by parts and objects of the yurt is the Sun.

Together with the dark time of the day, the most beautiful celestial bodies - the stars - appear in the sky. The approach of night is characterized by the position of the constellations above the yurt.

At night, through the smoke hole of a yurt, one can "watch the movement of the universe at night, since the movement of stars, bounded by a cross in a circle, like in a crosshair of sight, is easily perceptible and tangible" (Darzha, 2007: 48).

(9) Uger syldys og dunduunden kharap orda, Duruiaa kyrgan Yraazhy-Khem dugaiynda bir toolchurgu chuve chugaalaan. "When the constellation of the Pleiades was seen from the smoke hole of the yurt, old Duruiaa told one legend about Yraazhy-Khem."
7. The constellation Chedi-Khaan (Big Dipper) served as the main landmark in the dark. Night time is determined by the position of the constellation above the honorary place of the yurt.

(10) Chedi-Khaan og dorunde turgan. " "The constellation Big Dipper was above the honorary place of the yurt."

8. Early morning is characterized by the position of the constellation Uger (Pleiades), Chedi-Khaan (Big Dipper) above the door of the yurt.

(11) Uger ezhik kyrynda kelgen-daa bolza, bichii bazhynda ush kizhi aiaar chugaalashpyshaan olurgan. "Even when the constellation of the Pleiades hung over the door of the yurt, three people were still talking quietly in the small house."

Thus, a single view of the time among the representatives of the Tuvan ethnos consisted of the interaction of its cyclical and linear understanding, objective and subjective principles, traditional views and the new that had come with the development of science and culture. The revealed lexical units with the seme ue (time) in the linguistic view of the Tuvinian world reflect the temporal space model of the Tuvinian space-time continuum.

\footnotetext{
SSur Atesh S. Surun-ool. Ak-Tesh. Kyzyl, 1984. P. 130.

ShK B Vol. 1. Sh. Kuular. Baglaash. Vol. 1. Kyzyl, 2002. P. 30.

MKL ChCh M. Kenin-Lopsan. Chogaaldar chyyndyzy. Kyzyl, 1993. P. 334.

SS At S. Saryg-ool. Angyr-ooldun toozhuzu. Kyzyl, 2008. P. 100.

SS At S. Saryg-ool. Angyr-ooldun toozhuzu. Kyzyl, 2008. P. 100.

ED Ekh E. Dongak. Ergi Khonashtar. Kyzyl, 1983. P. 44.

KK UChUKh Vol. 1. K-E. Kudazhy. Uigu chok Ulug-Khem. Vol. 1, Kyzyl, 1996. P. 98.

KK UChUKh Vol. 2. K-E. Kudazhy. Uigu chok Ulug-Khem. Vol. 2, Kyzyl, 2002. P. 165.

MKL Che M. Kenin-Lopsan. Chylgychynyn өө. Kyzyl, 2010. P. 320.

KK UChUKh Vol. 2. K-E. Kudazhy. Uigu chok Ulug-Khem. Vol. 2, Kyzyl, 2002. P. 19.

ShK B Vol. 2. Sh. Kuular. Baglaash. Vol. 2. Kyzyl, 2005. P. 44.
}

\section{References}

Darzha, V.K. (2007). Tainy mirovozzreniia tuvintsev-nomadov [Secrets of the world view of Tuvinian nomads]. Kyzyl, Tuvan book publishing house.

Kenin-Lopsan, M.B. (1999). Tyva chanchyl. Tyva Chonnun ydyktyg chanchyldary. Kyzyl, Novosti Tuvy. 
Kornilov O.A. (2003). Jazykovye kartiny mira kak proizvodnye nacional'nyh mentalitetov [Language pictures of the world as derivatives of national mentality]. M.: CheRo.

Potapov, L.P. (1969). Ocherki narodnogo byta tuvintsev [Essays on the people's life of the Tuvinians]. Moscow, Nauka.

Traditsionnoe mirovozzrenie tiurkov Iuzhnoi Sibiri. Prostranstvo i vremia. Veshchnyi mir [Traditional worldview of the Turks of Southern Siberia. Space and time. Real world]. (1998). Novosibirsk, Nauka.

Tsiv'ian T.V. (2006). Model' mira i ee lingvisticheskie osnovy [The world model and its linguistic basis]. Moscow, KomKniga.

\section{Традиционное представление времени у кочевых тувинцев}

Ш.Ю. Кужугет

Тувинский государственный университет Россия, 667000, Республика Тыва, Кьззыл,

ул. Ленина, 36

В статье рассматривается традиционное представление времени у кочевых тувинцев. Особое внимание уделено темпоральным лексическим единицам со значением суточных отрезков времени, которые тувинцы выражали по частям и предметам быта юрты.

Ключевые слова: языковая картина мира, время, средства выражения, суточный циикл, национальная спечифика, юрта.

Научная специальность: 24.00.01 - теория и история культуры. 